\title{
EDUCATIONAL COOPERATION BETWEEN CHURCH AND STATE
}

\author{
Alexander Merklejohn*
}

"Congress shall make no law respecting an establishment of religion, or prohibiting the free exercise thereof. ...."

In a number of recent cases the Supreme Court has attempted to determine, in specific references, the present meaning of those words. The writer of this paper would like to record, concerning opinions expressed by members of the Court in the discussion of these cases, some reflections which have arisen out of a long participation in the teaching of American college and adult classes.

\section{I}

The basic question underlying all controversies concerning educational cooperation between church and state is this: Have these two institutions any community of purpose? It is, of course, obvious that they have a sharp diversity of purposes. In Jefferson's words, there is a "wall of separation"1 between them. But how high and wide and thick is that wall? Are there any gates in it? Or is the barrier so impregnable that every form of cooperation for a common purpose is negated and forbidden by the Federal Constitution?

As we face this question it must at once be noted that even if cooperation were shown to be desirable, that would not insure an affirmative answer. Other, more important reasons might outweigh that desirability. But this secondary issue can be more wisely dealt with after the primary issue has been carefully considered. What then, if any, are the relations between church and state with respect to the aims of education?

In our American society, as it is now constituted, the churches and the governments, as the agencies of Church and State, have, clearly, a common interest in teaching. The process of enlightenment by which our citizens, young and old, are to be fitted for membership in a free society is not merely the equipping of their minds with knowledge. It is the cultivation of all their powers as persons so that they may, so far as possible, live in right relations with themselves, their fellows, and their world. To this end it is not enough that pupils learn to speak, to read, to write, to figure, to infer, to investigate. They must also acquire the attitudes, the sentiments, the habits, and the behaviors of democratic association. The Preamble to the Constitution defines in sweeping terms the purposes for which our government

\footnotetext{
- President, Amherst College, r912-1924; Professor of Philosophy and Chairman of the Experimental College, University of Wisconsin, 1926-1938.

${ }^{1}$ Saul K. Padover, The Complete Jefferson 5i8-519 (i947).
} 
was established and is now maintained. "We the People of the United States," it tells us, intend "to form a more perfect union, establish justice, insure domestic tranquillity, provide for the common defense, promote the general welfare, and secure the blessings of liberty to ourselves and our posterity...." Now, the educating of girls and boys, women and men, for membership in a society whose purposes are so defined requires not only "knowledge about" those purposes and the means of their realization, but also emotional and volitional adoption of those purposes as controlling motives in one's behavior. It requires the cultivation of loyalty, of devotion, of energetic activity in the common enterprise. Such loyalty may not, under our Constitution, be slavish. It may not be imposed "without consent." And yet the basic fact remains that, unless emotional and volitional health and sanity are achieved in the process of learning, education is, both for the society and for the individual, a hollow sham, a misleading mockery.

\section{II}

What has just been said about education rests upon the postulate that thinking and feeling, though different from one another, are dependent on each other. What we feel and do about any object determines, and is determined by, what we know and believe about it. Any man or society whose feelings are going in one direction while his ideas are going in another is, in so far, lacking in sanity and heading for breakdown. This means, for the teacher, that his pupils can properly be moved by devotion and loyalty only as they find, in the world and in the society of which they are members, objects and causes which seem to them to have great value. It is with respect to this interdependence of attitude and of belief that church and state have, ideally at least, a common educational purpose. To the inquiring mind of a young American who asks, "Why should I devote myself to that tremendous human enterprise outlined by the Preamble to the Constitution?" the churches answer, or should answer, "Because that enterprise is sanctioned, is approved, by the Mind and Will of God." For some 40 or 50 or 60 per cent of our people, that religious belief is made the necessary and sufficient source from which our democratic institutions derive their moral validity. But, meanwhile, for the remaining 60 or 50 or 40 per cent, the nonbelievers in religion, no such extra-human support is found to exist. They must, therefore, find their objects of loyalty within the human spirit itself. So far as these nontheological minds can see, humanity must supply its own ideal aims-but it must have aims. It must stand on its own feet-but it must have feet and learn to use them.

The statements just made reveal the basic dilemma which besets the relations of church and state, as they now deal with teaching. On the one hand, it is clear that the two institutions share a common educational purpose. They should therefore cooperate, supplementing each other. On the other hand, the bewildering multiplicity of conflicting beliefs has, over and over again, involved the attempts at cooperation in jealous, unreasoning controversies and persecutions. The religious 
believers in the United States are divided into hundreds of sects which spend quite as much of their energies upon their differences of belief as upon their unity of purpose. Likewise, the nonbelievers, staggering under the task of finding, within human inspiration itself, an adequate basis for our mode of life, have won, as yet, no secure forms of cooperation or, even, of mutual understanding. It is out of that intellectual chaos of disunity about unity, of disagreement about a common aim, that there has been raised, by all creeds and sects, the general demand that our Iegislative bodies "shall make no law respecting an establishment of religion, or prohibiting the free exercise thereof...."

\section{III}

As We, the People, seek, then, to advance by political action what may be called our "spiritual" community and, at the same time, to guard the freedom of our separate beliefs, as well as to keep peace among them, what are the limits within which we have confined our legislatures, in their dealings with religion and nonreligion?

Before we attempt a direct answer to that question, it is needful that two ambiguities be cleared away. The first of these is grammatical. The term "an establishment of religion," as it appears in the crucial sentence, may be either a noun or a participle. It may indicate either a social group or a social process. In the former case, an "establishment of religion" might be a local church, a YMCA, a monastery, a denomination, and so on. The statement would then be that "respecting" none of these social bodies may laws be made. They are, all alike, outside of legislative jurisdiction. This would mean, for example, that the property of a church could not be taxed. Nor could it be exempted from taxation. But that view, in the face of our well-established customs, is absurd and untenable. The "wall of separation," however wide or high it may be, does not run in that direction. Obviously, then, "establishment" as here used, means "establishing." What is forbidden is "the establishing of a religion."

Again, as is generally agreed, the decree of which we are speaking does not express hostility, either to religion or to nonreligion. Nor does it require of the government indifference to either of them. On the contrary, beliefs about the basic relations of an individual to himself, his society, his world, are of primary importance for the cultivation of civic virtues. We, the People, are, therefore, deeply concerned about them. And, especially, since they are "beliefs," we are concerned for their freedom, their independence. We will not have them interfered with, even by our own political institutions. No one of them shall be preferred to the disadvantage of the others. No one of them shall be declared valid while the others are regarded as heresies. Our legislatures are directed by the Constitution, not to be hostile to our varied attempts at spiritual understanding, not to be indifferent to them, but to be impartial in recognition of them, in dealings with them. Are they also directed to have nothing to do with them? That is the inquiry with which this argument is concerned. 


\section{IV}

The forms of legislation which our inquiry must consider are found on three levels. These are: ( $\mathrm{I}$ ) the "establishing" of one sect, (2) the giving of equal financial support to all sects, and (3) cooperation, without financial support, with all sects.

In the first case, some one religious or nonreligious belief is, by political action, set up as the creed of an "established" church. This procedure is overtly discriminatory. The sect in question is given legal status superior, in two respects, to that of its colleagues and competitors. First, a distinction between orthodoxy and heterodoxy is made and, in varying ways, the orthodox beliefs and ceremonies are woven into the fabric of the common life. Second, in return for this service to the community, subsidies are granted from the public treasury. There can be no doubt that such discrimination in status and support is, by the First Amendment, banned as an "establishing of a religion."

On the second level, all sects alike are recognized as seeking, in non-political ways, to serve the general welfare. On that basis they are, on equal status, granted such financial support, negative or positive, as the legislature may deem wise. An example of such nondiscriminatory action is the tax exemption of educational, religious, and philanthropic enterprises. It is not so clear that that "support" is an "establishing of religion."

The third level is that of cooperation, without discrimination and without support. Here, a Catholic church or some other group may be allowed, at its own expense, to substitute its teaching, wholly or in part, for that given by the public schools, under the regulations of required attendance. Should that substitution of sectarian teachings for the secular teaching be regarded as "establishing a religion"?

\section{$\mathrm{V}$}

The issues of which we are speaking came to sharp focus in the controversy presented to the Supreme Court by the McCollum (Champaign) case. ${ }^{2}$ The school authorities of Champaign, on the request of a representative group of parents and their churches, had adopted the "released time" plan of religious teaching. For a brief period each week, public school pupils were assigned to separate groups, on the basis of the religious affiliation of their parents. Each group was given, by outside teachers, religious instruction which was paid for by the parent church organizations. Separate rooms in the school buildings were used. The "outside" teachers were "approved" by the school authorities. The teaching, it must be noted, was to be not merely teaching "about" religion, but teaching "of" religion. In the opinion of a large majority of the Supreme Court, this arrangement was an "establishing of religion," and hence not allowable.

For the appraising of this judgment of the Court, it is essential to get clearly in mind the motives-the needs-of the parents (and their churches) upon whose request the arrangement was made. Those parents were caught in the desperate

${ }^{2}$ McCollum v. Board of Education, 333 U. S. 203 (1948). 
dilemma into which our culture has been plunged by its spiritual sectarianism. On one side, they recognized that no one sectarian faith could be taught to all the pupils in the public schools. On the other side, they saw that teaching which is given without what is here called "spiritual" grounding is, of necessity, inadequate and ill-motivated. Its structure is that of a house without foundations. The accepted solution of that dilemma has been that the homes, with their separate churches, should supplement the work of the school. They must see to it, each in its own terms, that the beliefs and sentiments which are, for it, the sources of common virtues, shall be effectively brought to bear upon the minds and spirits of their children. But that means, for the parents, that public education is broken into two separate parts. Where unity is needed, division is established. And the brutal fact must be faced that homes and churches, working against terrible odds, have had little success in their part of the teaching. In that situation, the "released time" plan is an attempt by parents and churches to diminish the damage done by their own sectarianism.

It should here be noted that, at least in the opinion of the writer of this paper, the "released time" plan gives little promise of securing its desired results. The cooperation which it sets up between home and school is pitifully small and external when measured by the educational need which it seeks to meet. Yet this inadequacy is, presumably, irrelevant to the issue which the Supreme Court was deciding. The parents, upon whom a heavy public responsibility has been laid, choose to try this way of carrying their burden. The Court is judging only whether or not, under the Constitution, the schools are forbidden to give to the parents the cooperation which their plan requires.

\section{VI}

In the opinions of the Court which justified the disapproval of the plan, it was not charged, on the first level, that one sect had become an "established church." On the second level, no direct financial support was involved, but some slight and incidental expenses were incurred by the schools. There were, for example, administrative arrangements which took the time of teachers and officials. The use of special rooms in the school buildings was allowed. But far more important than these aids, in the judgment of the majority, was cooperation on the third level. It was seen in the application of the truancy laws, as the requirement of attendance at the public schools was used to "compel" attendance at the sectarian classes. It was true that registration in any class was optional. It was made only by the free choice of the parents. But this arrangement was judged by the Court to be compulsion in the cause of religion. As expressed by Justice Black, the opinion said, "This is beyond all question a utilization of the tax-established and tax-supported public school system to aid religious groups to spread their faith." ${ }^{3}$ The state, we are told, gives the sects "invaluable aid in that it helps to provide pupils for their

sid. at 2 ro. 
religious classes through use of the State's compulsory public school machinery."

If we waive for the moment the doubtful charge of "compulsion," these sentences bring us to the basic issue in the controversy. Are the "released time" groups seeking to "spread their faith"? Is their purpose properly described, in the words of Justice Black, as "the dissemination of their doctrines and ideals"?

The most direct answer which a parent might give to the argument in this form would be a denial that the purpose or effect of a "released time" class is to "spread the faith," to "disseminate doctrines and ideals." "As our plan is conceived," he would say, "the faith, the doctrine, the ideals, have already been spread and disseminated through the family relationship. Our purpose is to use beliefs which are already held, to make them more effective in the service of that public welfare with which religion is concerned." In a word, this is a plan for teaching, not for proselyting.

But the issue, as formulated by Justice Black, comes to sharper focus than can be gained by the use of the somewhat blurred idea of parental authority, as now found on the American scene. His argument goes back to an earlier ruling of the Court, also written by him. In the Everson case ${ }^{\mathrm{b}}$ it was decided that a government may pay the bus fares of pupils attending parochial schools. Such support, it was ruled, is not an "establishing" of the Catholic Church. The paying of the fares, it was admitted, might increase the number of pupils brought under religious instruction. But that private effect of "spreading the faith" is merely accidental. It happens to coincide with the primary public purpose, which is "to help parents get their children, regardless of their religion, safely and expeditiously to and from accredited schools."

At this point, Justice Black is basing his argument upon the fundamental constitutional distinction between public and private interests. Getting pupils safely to and from school is, he says, a public purpose. But giving them religious instruction is a private purpose; it seeks merely "to satisfy the desires of private individuals." Upon the validity of that distinction, the McCollum decision, as Justice Black argues it, rests.

As one questions the distinction here made, one is not denying that parents have a private interest in religious teaching. But they have, likewise, a private interest in the physical safety of their children. In this respect the two cases are identical. But the presence of a private desire does not prove the absence of a public need. And the values to be gained by religious teaching are not merely private. To say that is to rob religious attitudes of all objective "spiritual" meaning. It is to reduce their significance to that of private personal idiosyncrasies. As against such false sectarianism, surely the value of all our creeds, religious or nonreligious, lies in their common, though varied, attempt so to interpret men and society and the world as to find, in those interpretations, bases for human behavior, for human

\footnotetext{
4 Id. at $2 \times 2$.

"Id. at $2 \mathrm{rr}$.

'Everson v. Board of Education, 330 U. S. I (1947).

"Id. at 58.
} 
association. In relation to that common purpose, creedal differences are accidental. Our sects can live together in peace, not by ignoring each other as "private," but by recognizing and honoring one another as fellows in a common cause. Just as the teaching of geography is "public," so is the teaching of religion or nonreligion. In whatever varied ways are available, the general welfare requires that our young people learn the lessons which we call "spiritual."

The argument just stated seems to require that the writer of these words indicate, if not explain, his own "private" conviction. My own beliefs are definitely on the side of nonreligion. So far as I can see, human purposes have no extra-human backing. Yet, so long as half our people, more or less, are interpreting and conducting their lives, their family relationships, the upbringing of their children upon a basis of some religious belief, the Constitution requires of us that those beliefs shall be given not only equal status but also positive status in the public planning of education. The freedom of religion has the same basic justification as has the freedom of speech or of the press. In both sets of cases, a strong and passionate private desire is involved. But far deeper than this is a public necessity. When men are trying to be self-governing, no other single factor of their experience is more important to them than the freedom of their religion or of their nonreligion. The interpreting of our spiritual beliefs is a public enterprise of the highest order.

VII

One of the strangest features of Justice Black's contention in the McCollum case is its apparent incongruity with the Court's approval of the parochial school system which had been given in the case of Pierce v. Society of Sisters. ${ }^{8}$ Referring to that earlier ruling, Justice Black says in the Everson case, "This Court has said that parents may, in the discharge of their duty under state compulsory education laws, send their children to a religious rather than a public school if the school meets the secular educational requirements which the state has power to impose." But in the McCollum case, he says, "Pupils compelled by law to go to school for secular education are released in part from their legal duty upon the condition that they attend the religious classes. This is beyond all question a utilization of the tax-established and tax-supported school system to aid religious groups to spread their faith."10 But the two arrangements which are thus contrasted differ at only one essential point. One of them is partial while the other is total. Under the "released time" plan pupils are released "in part" from their legal duty. Under the parochial school plan they are released altogether. In both cases attendance is "compelled by law" for the sake of what Justice Black calls "the spreading of faith." Why, then, is the partial release regarded as an "establishment of religion" while the total release for the same purpose is not so regarded? It would seem that if the McCollum decision

${ }^{8} 268$ U. S. 5 ro (1925).

Everson v. Board of Education, supra note 6, at $\mathrm{x} 8$.

${ }^{10} \mathrm{McC}$ Collum v. Board of Education, supra note 2, at 209-210. 
stands, the parochial school system, together with all other religious school systems, must be abolished. And, by direct implication, if the schools are to remain, the decision must go.

\section{VIII}

It is a curious and confusing fact that attacks upon the "released time" plan have been far more commonly based upon a remark of Thomas Jefferson, as he commented on the First Amendment, than upon the text of the amendment itself. Arguments are drawn not so much from "no law respecting an establishment of religion" as from "thus building a wall of separation between church and state."11 This is the line followed by Justice Frankfurter as he takes a different road toward the same conclusion which Justice Black had reached. In the course of his carefully elaborated historical argument, Justice Frankfurter does not once mention the relevant words which the First Amendment uses. Rather, he takes his stand on what he quotes Elihu Root as calling "the great American principle of eternal separation"12 of church and state. That procedure needs careful watching. The idea of the separation of church and state has undoubtedly had very great influence upon our political thinking. But what is the evidence that it expresses the meaning of "no law respecting an establishment of religion"? Is the idea of "eternal separation," in the extreme form in which Mr. Root states it, an "American" principle? Or is it, on the contrary, a sectarian "Protestant" principle? Here is a fundamental question which must not be begged.

As one follows the evidence which Justice Frankfurter gives, it becomes clear that, under the stress of controversial debate, Jefferson's phrase has been pushed to the limit of its possible figurative meaning. In the Everson decision, for example, we are told that the wall of separation "must be kept high and impregnable. We could not approve the slightest breach."13 But, as against this extreme assertion, Justice Reed, in his lonely $M c$ Collum dissent, has cited a convincing number of instances in which our political and educational activities are shot through with religious beliefs and ceremonials. The practices of church and state are not, in fact, kept separate.

Perhaps the most significant instance which Justice Reed gives us is that of Jefferson's plans for religious education and worship in connection with the University of Virginia, of which he was founder and Rector. Reporting to his governing board, he said, "It was not, however, to be understood that instruction in religious opinion and duties was meant to be precluded by the public authorities, as indifferent to the interests of society. On the contrary, the relations which exist between man and his Maker, and the duties resulting from those relations, are the most interesting and important to every human being, and the most incumbent on his study and

\footnotetext{
${ }^{11}$ See note $\mathrm{I}$, supra, and the dissenting opinion of Justice Reed in the McCollum case, supra note 2, at 244-245 n. 8.

${ }_{12}$ McCollum v. Board of Education, supra note 2, at $23 \mathrm{~T}$.

${ }^{15}$ Everson v. Board of Education, supra note 6, at 18 .
} 
investigation." For that reason, the Rector suggests a plan which, "while it excludes the public authorities from the domain of religious freedom, will give to the sectarian schools of divinity the full benefit the public provisions made for instruction in the other branches of science. ..." The plan is to allow the sects "to establish their religious schools on the confines of the University. ..." This would have the advantage of "enabling the students of the University to attend religious exercises with the professor of their particular sect, either in the rooms of the building still to be erected ... or in the lecturing room of such professor...." And he continues, "Such an arrangement would complete the circle of the useful sciences embraced by this institution, and would fill the chasm now existing, on principles which would leave inviolate the constitutional freedom of religion, the most inalienable and sacred of all human rights. ..."14

As one reads those words of Jefferson, his "wall of separation" stands fast, but its usefulness is not that assigned to it by Mr. Root or Justice Frankfurter. He knew as well as they that "the public authorities" must be excluded from "the domain of religious freedom." But he knew also that to reduce "public" education to "secular" education was to destroy it at its very roots. Thomas Jefferson should not be listed as the original opponent of the "released time" plan. It would be nearer the truth to say that he was one of its first advocates.

\section{IX}

The shift in the meaning of Jefferson's "wall of separation" is a striking illustration of the change from the organic to the mechanical interpretation of a figure of speech. As one reads the words of the Rector of the University of Virginia, it is clear that the beliefs and attitudes of religion are, for him, "separated" from the other factors in education in much the same way as is the bloodstream of a living body from its other structures and functions. That bloodstream must be kept separate by the walls of the circulatory system. A break in them is disastrous. And yet the blood performs its living function only as it nourishes the whole body, giving health and vigor to all its activities. It is some such organic meaning as this which seeks expression in Jefferson's "wall of separation." But men who claim to follow him have transformed his figure into one of mechanical divisions and exclusions. They speak of his wall as if it were made of brick or stone or steel. By so doing they cut off our spiritual education from its proper field of influence. They make "private" a matter of supreme "public" importance. And the effect of that operation corresponds closely to what would happen if we should substitute for the living tissues which enclose the cortex, or the nerves, or the blood, casings of impenetrable steel.

\section{$\mathrm{X}$}

The main purpose of Justice Frankfurter's argument is to define the term "separation" as used in Jefferson's phrase. The term, he tells us, means more than the for-

\footnotetext{
14 The Writings of Thomas Jefferson 4I4-4I7 (Memorial Ed. Ig04), quoted by Justice Reed in his dissenting opinion in the McCollum case, supra note 2, at 245-246 n. II.
} 
bidding of an "established church." It means more than the absence of discrimination in the government's relations with the sects. "Separation," he says, "is a requirement to abstain from fusing functions of government and of religious sects, not merely to treat them all equally."15

The evidence which Justice Frankfurter presents in support of that statement may be summed up in the assertion that, in the course of our history, there has developed a strong sentiment in favor of "the separation ... of the State from the teaching of religion." After the Civil War, we are told, "so strong was this conviction that rather than rest on the comprehensive prohibitions of the First and Fourteenth Amendments, President Grant urged that there be written into the United States Constitution particular elaborations, including a specific prohibition against the use of public funds for sectarian education, such as had been written into many State constitutions." 17 This sentiment became so strong, it is further said, "that every State admitted into the Union since 1876 was compelled by Congress to write into its constitution a requirement that it maintain a school system 'free from sectarian control." "18

In assessing the value of this evidence, the reference to freedom from "sectarian" control may, of course, be disregarded since we are discussing the constitutionality of "nondiscriminatory" action. Our question is, then: If government aid to the sects treats them equally, are such aids banned by the First Amendment? It would seem that, in relation to this question, the facts which Justice Frankfurter offers, if they prove anything at all, tend to prove the exact opposite of what he is saying. Surely the statement that President Grant wished to amend the Constitution to give it a certain meaning gives no evidence that it already had that meaning.

The essential difficulty with Justice Frankfurter's argument is the wide logical gap between the statements, "Majority opinion in the United States strongly favors policy X," and "Policy X was written into the Constitution." A most convincing illustration of this logical difference can be seen if we examine the relation between two political actions taken by James Madison. In the Virginia legislature, Madison bitterly and persistently opposed a plan for nondiscriminatory aid to religious education. Against it he wrote his great Remonstrance. ${ }^{19}$ Yet, when he proposed to the Constitutional Convention a provision for the defense of religious freedom, his recommendation did not forbid such aid. That recommendation was stated as follows: "The civil rights of none shall be abridged on account of religious belief or worship, nor shall any national religion be established, nor shall the full and equal rights of conscience be in any manner, or on any pretext, infringed."20 Now, in that statement, only the second clause is relevant to our issue. And the plain fact is that that clause

${ }^{15} \mathrm{McC}$ Collum $\vee$. Board of Education, stupra note 2, at 227.

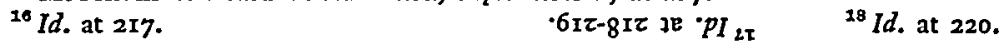

${ }^{10}$ Memorial and Remonstrance Against Religious Assessments, II The Writings of James Madisos 183 (Hunt ed. I90r), reprinted as an appendix to Justice Rutledge's opinion in the McCollum case, supra note 2 , at $63-72$.

${ }^{10} \mathrm{I}$ ANNALS OF CoNGress 434 (1789-179r). 
does not outlaw plans for equal aid to religious education. By no interpretation of terms could the banning of "a national church" be taken to mean that the government may not, on equal terms, give aid and cooperation to the many churches. In a word, though opposition to the equal-aid plan was one of Madison's most passionate convictions, he did not, in his original proposal, recommend that such plan should be outlawed by the Constitution.

This contrast between the two attitudes taken by Madison suggests the corresponding contrast in our contemporary dealings with the relations between church and state. For example, for us as for him, the question whether or not government grants, on equal terms, may be made to Catholic and other religious or "non-religious" schools, is a matter to be decided by legislative action. It may, presumably, be taken for granted, as Justice Frankfurter suggests, that the prevailing sentiment of the nation is, at present, strongly against such grants. But that may not be taken to mean that, by decree of the Federal Constitution, we are committed against them. The same distinction holds good for our dealings with the "released time" plan, though the opposition here is not so strong. That plan has great disadvantages. It should not be adopted if any better plan can be found to take its place. But the "on principle" disapproval of the plan is not, on that ground, justified. It seems to spring primarily from the mutual suspicions and hostilities of the sects, rather than from a generous cooperation in the cause of public education. As such, it seems to the writer to have no proper place in the Constitution. Whether that be true or not true, no satisfactory evidence has been offered to show that in the making of the Constitution such a place has been assigned to it.

\section{XI}

In conclusion, three explanatory remarks may be made where many are needed.

First, all discussions of the First Amendment are tormented by the fact that the term "freedom of religion" must be used to cover "freedom of nonreligion" as well. Such a paradoxical usage cannot fail to cause serious difficulties, both theoretical and practical. A striking case in point is the failure of the Champaign plan to provide special instruction for nonreligious groups. The root of the difficulty lies in a prevalent hypocrisy which allows a person to be a nonbeliever but which blames his conduct as socially improper if he openly professes his atheism.

Second, underlying all that has been argued in this paper is the strong conviction that our American education has been robbed of its spiritual sustenance by the sterile negativism of a separation doctrine which can express itself in the phrase, "A state without religion and a church without politics." For the purposes of education, the vital question is not How can the churches and the government be kept apart? but How can the many sects, religious and nonreligious, with due regard for the sectarian freedom of each, work together for the promoting of the general welfare? We shall not accomplish that purpose by arranging that, in every way 
possible, the teaching of our children and adults shall be cut off from our attempts to understand ourselves, our society, and our world.

Finally, at the very bottom of the problem of religious teaching is the question of the difference between public and private interest. On that issue, the writer of this paper wrote, some months ago, "What then, is the distinction between, and the relation between, the common good and our many different private goods? On no problem of our national life is the American mind more confused than on this problem.... Unless this relation can be made clear, nothing which has to do with political freedom can be understood."21 The McCollum decision seems to the writer to have deepened, rather than to have cleared away, the current confusion about that basic issue. Education is our greatest public enterprise, and at the heart of it is that attempt to interpret the meaning of human existence around which our religious and nonreligious controversies rage.

22 Alexander Meiklejohn, Free Speech and Its Relation to Self-Government 94-95 (1948). 